\title{
Reconceptualizing ways of studying teacher learning: working with teachers rather than conducting research on teachers
}

\author{
Alison Castro Superfine ${ }^{1}$
}

Published online: 16 January 2019

(c) Springer Nature B.V. 2019

Recent discussions in the education research community about impacting teacher learning have begun to highlight the importance of actively engaging with teachers to design and implement professional learning experiences. Research on professional learning experiences for teachers has consistently revealed the challenges of impacting teacher practice, including the need for a variety of learning experiences and the considerable time needed for teachers to change their practice in the intended ways. On the one hand, we have learned that certain features of professional learning experiences can make them more effective, such as inquiry into teaching and learning, learning in ways that model particular pedagogical approaches, ongoing reflection on one's own practice and learning, working with colleagues to translate ideas into their specific contexts and ongoing support for their learning (e.g., Geiger et al. 2016; Kazemi and Franke 2004; Slavit and Nelson 2010; Steinberg et al. 2004). But on the other hand, we have long known that most professional learning experiences are relatively short in duration and fail to provide ongoing support. The result is often that they end long before changes in teacher practice are able to take root.

Perhaps just as importantly, many such efforts have been less successful when implemented in contexts beyond those in which they were originally developed. That is, adaptation of professional learning opportunities to new contexts tends to not be particularly successful (McDonald et al. 2006; RAND 2004). In response, some researchers have proposed new models of working with teachers that hold much promise for productively adapting professional learning experiences to new settings and contexts. Examples include Network Improvement Communities that draw on principles of improvement science (Bryk et al. 2015), Design-based Implementation Research (Penuel et al. 2011) and research-practice partnerships (Coburn and Penuel 2016). These models tend to situate teacher learning in problems of practice that teachers see as relevant to their own contexts and circumstances, and engage teachers as collaborators in the design and implementation processes.

Common across all of these emerging models is that researchers work with teachers as opposed to doing research on teachers. Such models offer new conceptualizations of teacher learning and afford new opportunities and designs for studying teacher learning over time. For example, all three of the examples noted above involve iterative cycles of

Alison Castro Superfine

amcastro@uic.edu

1 Chicago, USA 
improvement wherein teachers receive feedback on their practice and have opportunities to implement that feedback and, together with researchers, collaboratively examine the underlying design mechanisms that contribute to changes in teaching practice over time. In these ways, emerging models for working with teachers can not only support the productive adaptation of professional learning experiences to new settings and contexts, but also provide opportunities to study teacher learning over time. When teachers are engaged as co-designers and co-implementors of professional learning experiences, we can better understand what is working, for whom and under what conditions (Erikson 2014), thereby increasing the likelihood that changes in teacher practice can take root.

The articles in this issue of the Journal of Mathematics Teacher Education (JMTE) take up several of these issues, either explicitly through the theoretical frameworks employed to study teacher learning or implicitly through the questions raised from the study findings. For example, in her study, Wilkie focuses on ways of promoting teacher change through two different models of school-based learning and identifying the internal and external influences teachers perceive as impacting their professional learning. Wilkie argues for a view of teacher professional learning that is aimed at "...helping teachers change their teaching practice rather than seeking to change the teachers per se...". One part of the theoretical framework the author employed to study teachers includes a model of teacher learning, meta-didactical transposition (MDT) (Arzarello et al. 2014), which considers the bidirectional nature of the relationship between teachers and researchers, acknowledging that each may learn from each other. The MDT model highlights the mutual influence between teachers and researchers when engaged in efforts to change teacher practice and that researchers may in fact change how they think about or interpret a teaching situation because of this mutual relationship. Wilkie examines, from teachers' perspectives, aspects of their professional learning experiences that contributed to or constrained efforts to change their teaching practice.

Earnest and Amador examine how prospective teachers use digital animations to understand how prospective teachers use curriculum materials for purposes of enactment. Drawing from research on teacher curriculum use and the use of approximations of practice in teacher preparation, the authors consider the use of "lesson planimations" as approximating the teaching practices of curricular analysis and lesson planning, key aspects of teachers' work in the classroom. One part of their theoretical framework acknowledges a mediation process between teachers and the curriculum materials they use in their work. Specifically, "...there is a dialectic relationship between teacher and text in which curricular elements... inform how a teacher envisions instruction while, at the same time, that teacher brings a perspective and way of thinking reflective of her own experiences." Might there be such a dialectic relationship between teacher and researcher wherein researchers inform how a teacher envisions their practice while, at the same time, the teacher brings a perspective and way of thinking about teaching practice that is reflective of their own experience? Earnest and Amador's study also raises questions about how reconceptualizing research with teachers might look like in a university context. What might it look like to work with prospective teachers rather than on when designing tasks, activities, or even course interventions in teacher preparation? Indeed, there is need for empirical evidence about the institutional constraints of working in universities or colleges that might preclude researchers from reconceptualizing ways of working with prospective teachers within teacher preparation programs.

Rather than teaching teachers to use particular instructional strategies or certain tasks to elicit the desired mathematical practices, Otten, Keazer and Karaman engaged teachers in a study group over several weeks to provide opportunities for teachers to reflect 
on and discuss ideas related to the mathematical practice of attending to precision. The authors found that the ways in which teachers talked about precision provided insight into how they attended to precision in their teaching practice and how teachers interpreted the mathematical practice of attending to precision more generally. How might we leverage these findings to inform the design of professional learning opportunities for teachers wherein teachers and researchers co-design these opportunities? How might the dilemmas, or problems of practice, raised by teachers in this study be leveraged to serve as the foundation for such a co-design process?

Finally, Yopp, Burroughs, Sutton and Greenwood examined how changes in schoolbased mathematics coaches' knowledge and practices over time could explain coaches' effectiveness. In contrast to causal studies that measure the impact of professional development efforts on school-based coaches' or teachers' knowledge and practices, the authors examined coaches' effectiveness by measuring changes in coaches' knowledge and practices in order to explain changes in teachers' measures. In particular, their findings support the hypothesis that improvements in certain types of coaching knowledge and practices explained the effects of coaches on the improvements seen in teachers' knowledge, efficacy and practices. The authors describe how their findings might enable them to make recommendations to schools about how best to select the types of professional development for coaches given various organizational features, including funding. How might coaches collaborate with researchers to inform such recommendations? Given school-based coaches' proximity to supporting teachers' practice, how might we leverage these findings to engage coaches in co-designing and co-implementing professional development for teachers?

Together these studies highlight how researchers might consider ways of reconceptualizing ways of studying teacher learning. By engaging in research with teachers, we can better understand the processes by which and principles underlying how and why teachers make shifts in their practice (Bereiter 2014).

\section{References}

Arzarello, F., Robutti, O., Sabena, C., Cusi, A., Garuti, R., Malara, N., et al. (2014). Meta-didactical transposition: A theoretical model for teacher education programmes. In A. Clark-Wilson, O. Robutti, \& N. Sinclair (Eds.), The mathematics teacher in the digital era (pp. 347-372). Dordrecht: Springer.

Bereiter, C. (2014). Principled practical knowledge: Not a bridge but a ladder. Journal of the Learning Sciences, 23(1), 4-17.

Bryk, A., Gomez, L., Grunow, A., \& LeMahieu, P. (2015). Learning to improve: How America's schools can get better at getting better. Boston, MA: Harvard Education Publishing.

Coburn, C., \& Penuel, W. (2016). Research-practice partnerships: Outcomes, dynamics, and open questions. Educational Researcher, 45(1), 48-51.

Erikson, F. (2014). Scaling down: A modest proposal for practice-based policy research in teaching. Education Policy Analysis Archives, 22(9), 1. https://doi.org/10.14507/epaa.v22n9.2014.

Geiger, V., Muir, T., \& Lamb, J. (2016). Video-stimulated recall as a catalyst for teacher professional learning. Journal of Mathematics Teacher Education, 19, 457-475.

Kazemi, E., \& Franke, M. (2004). Teacher learning in mathematics: Using student work to promote collective inquiry. Journal of Mathematics Teacher Education, 7(3), 203-235.

McDonald, S. K., Keesler, V. A., Kauffman, N. J., \& Schneider, B. (2006). Scaling up exemplary interventions. Educational Researcher, 35(3), 1524. 
Penuel, W., Fishman, B., Cheng, B., \& Sabelli, N. (2011). Organizing research and development at the intersection of learning, implementation and design. Education Researcher, 40(7), 331-337.

RAND. (2004). Expanding the research of education reforms: What have we learned about scaling up educational interventions (Research Brief). Santa Monica, CA: RAND.

Slavit, D., \& Nelson, T. (2010). Collaborative teacher inquiry as a tool for building theory on the development and use of rich mathematical tasks. Journal of Mathematics Teacher Education, 13(3), 201-221.

Steinberg, R., Empson, S., \& Carpenter, T. (2004). Inquiry into children's mathematical thinking as a means to teacher change. Journal of Mathematics Teacher Education, 7(3), 237-267.

Publisher's Note Springer Nature remains neutral with regard to jurisdictional claims in published maps and institutional affiliations. 